\title{
Efikasi Diri Pembatasan Cairan \\ Terhadap Intradialytic Weight Gain Pasien \\ Gagal Ginjal Kronik di Ruang Hemodialisa RSUD Pasar Minggu
}

\author{
Ni Putu Priska ${ }^{1}$, Santi Herlina ${ }^{2}$ \\ ${ }^{1,2}$ Fakultas Ilmu Kesehatan Universitas Pembangunan Nasional Veteran Jakarta \\ Jalan Limo Raya Kelurahan Limo Kecamatan Limo Kota Depok Kode Pos 16515 \\ Email : niputupriska@upnvj.ac.id ${ }^{1}$, santiherlina@upnvj.ac.id ${ }^{2}$
}

\begin{abstract}
Abstrak
Masalah yang umum muncul yang dialami oleh pasien yang menjalani terapi hemodialisa berkaitan dengan ketidakpatuhan mereka terhadap intake cairan. Ketidakpatuhan pasien gagal ginjal dapat menyebabkab kelebihan volume cairan dalam tubuh. Pemantauan keberhasilan manajemen intake cairan dapat diukur dengan Intradialytic Weight Gain (IDWG). IDWG dipengaruhi oleh beberapa faktor, salah satunya adalah efikasi diri. Penelitian ini bertujuan untuk mengetahui hubungan antara efikasi diri pembatasan cairan dengan IDWG pada pasien gagal ginjal kronik yang menjalani hemodialisa di RSUD Pasar Minggu. Penelitian ini menggunakan desain penelitian survei analitik dengan metode cross sectional. Efikasi diri pembatasan cairan diukur menggunakan kuesioner, sedangkan IDWG diobservasi selama pre dan post hemodialisa sesuai dengan jadwal hemodialisa pasien. Dari 40 responden yang menjalani hemodialisis di RSUD Pasar Minggu, 20 pasien memiliki efikasi diri tinggi dan 20 pasien lagi memiliki efikasi diri rendah. Sedangkan rata rata kenaikan IDWG pada pasien adalah $2.188 \mathrm{Kg}$. Uji statistic menggunakan Man Whitney test menunjukkan adanya hubungan antara efikasi diri pembatasan cairan dengan IDWG $(\mathrm{p}=0.001, \alpha=0,05)$. Dengan demikian efikasi diri dapat mempengaruhi IDWG.
\end{abstract}

Kata Kunci : : kepatuhan, efikasi diri pembatasan cairan, IDWG

\section{Abstract}

The common problems experienced by patients undergoing hemodialysis related to their non adherence againts the intake of fluids. Non adherence of patients with renal failure can causes excess volume of fluid in the body. To monitoring the success management of fluids intake can be measured by the Intradialytic Weight Gain (IDWG). IDWG was influenced by several factors, one of which factors is self-efficacy. The research's aim is to know the relationship between self-efficacy's fluid restriction with IDWG on chronic renal failure patients undergoing hemodialysis at RSUD Pasar Minggu. This research use analytic survey design with Cross Sectional approach. Self-efficacy's fluid restriction measured by using questionnaires, whereas IDWG observed during pre and post hemodialysis accordinng to patient's schedule. Of 40 respondents undergoing hemodialysis in RSUD Pasar Minggu, 20 patients have high self-efficacy and 20 other patients have low self-efficacy. While the averange of IDWG on patients is 2,188 Kg. The satistical test using Mann Whitney test shows that there is a relationship between self-efficacy's fluid restriction and IDWG ( $p$ value $=0,001, \alpha=0,05)$. Thus, self-efficacy can affect IDWG.

Keywords $\quad$ : adherence, self-efficacy's fluid restriction, IDWG 


\section{Pendahuluan}

Gagal ginjal kronik merupakan menurunnya fungsi ginjal yang berpengaruh pada kemampuan ginjal untuk mengeliminasi produk limbah tubuh, mempertahankan asam basa, cairan dan keseimbangan elektrolit ${ }^{1}$.Penyebab utama gagal ginjal kronik adalah diabetes melitus (32\%), hipertensi (28\%) dan glumerulonefritis (45\%). Gagal ginjal kronik akan melewati 4 yahap yaitu penurunan cadangan ginjal, insufisiensi ginjal, gagal ginjal dan end-stage renal disease. ${ }^{2}$

Menurut US Renal Data System, pada akhir 2003 terdapat total 441.051 pasien gagal ginjal kronik yang menerima perawatan dan sebanyak $66 \%$ mendapatkan terapi hemodialisa. Data ini juga mengalami kenaikan dalam kurun waktu 1998 - 2008 sekitar $20-25 \%$. Berdasarkan data dari Riskesdas tahun 2013, peningkatan tajam penderita gagal ginjal kronik dialami oleh kelompok usia $35-44$ tahun $(0,3 \%)$ diikuti usia 45 - 54 tahun $(0,4 \%)$ dan kelompok usia $55-74$ tahun $(0,5 \%)$. Kelompok usia tertinggi adalah $>75$ tahun $(0,6 \%)$. Prevalensi laki - laki $(0,3 \%)$ lebih tinggi dari perempuan $(0,2 \%){ }^{3}$

Masalah yang umum muncul yang dialami oleh pasien yang menjalani terapi hemodialisa berkaitan dengan ketidakpatuhan pembatasan cairan. Hal ini dapat memicu kelebihan cairan dalam tubuh (overload). Kelebihan volume cairan dapat menyebabkan edema di sekitar tubuh,. Kondisi ini akan membuat tekanan darah meningkat dan memperberat kerja jantung. Kelebihan volume cairan juga dapat menyebabkan sesak nafas. Hal lain yang terjadi pada pasien gagal ginjal kronik yang tidak membatasi cairan adalah peningkatan berat badan melebihi berat badan normal $(0,5 \mathrm{~kg} / 24 \mathrm{jam}))^{5,6}$

Keberhasilan manajemen cairan dan diet pada terapi hemodialisa dianalisa dengan IDWG (Intradialytic Weight Gain). IDWG digunakan untuk mengevaluasi bagaimana pasien mengatur intake cairan, yang di kalkulasi dalam kilogram atau sebagai presentasi berat badan kering pasien. Untuk menurunkan resiko overload diantara waktu dialisis, IDWG sebaiknya harus kurang dari $2,5 \mathrm{~kg}$ atau $5 \%$ dari berat badan diantara dua sesi dialisis ${ }^{6}$. Dalam hal ini, megindikasikan bahwa pasien hemodialisa disarakan intake cairan perhari yang diperbolehkan adalah 500 $\mathrm{ml}$ ditambah jumlah total urine output perhari ${ }^{6}$. Di Amerika serikat, dilaporkan sebanyak 9,7\% - 49,5\% pasien mengalami kenaikan IDWG. Selain itu di Eropa, sebanyak 9,8\% - 70\% pasien mengalami kenaikan $\mathrm{IDWG}^{7}$.

Hal yang mempengaruhi Intradialytic Weight Gain (IDWG) selama periode terapi hemodialisa salah satunya adalah efikasi diri. Efikasi diri dapat didefiniskan sebagai proses individu dalam mencapai suatu kemajuan dan mampu melakukan kegiatan kehidupan seharihari sebanyak mungkin. ${ }^{8}$

Dari hasil studi pendahuluan di RSUD Pasar Minggu dengan wawancara kepada pasien sebanyak 10 orang, didapatkan hasil 7 diantaranya mengalami kenaikan berat badan diatas 2,5 kg. Beberapa hal yang mempengaruhi kenaikan IDWG ini antara lain, pasien masih belum mematuhi pembatasan cairan meskipun sudah diberikan edukasi dan arahan dari rumah sakit. Mereka mengaku bahwa sulit menahan rasa haus di rumah ditambah dengan cuaca yang panas. Selain itu, perilaku pasien menjelang jadwal dialisis yang tidak memperhatikan masukan makanan dan cairan menjadi pemicu IDWG meningkat sebelum dialisis.

Tujuan penelitian ini adalah untuk menganalisis hubungan antara efikasi diri pembatasan cairan terhadap IDWG. Selain itu, faktor - faktor lain (variabel perancu) dalam penelitian ini seperti usia, jenis kelamin dan lama HD juga dianalisis berdasarkan hubungannya terhadap IDWG.

\section{Metode}

Penelitian ini menggunakan metode survei analitik dengan pendekatan cross sectional. Metode sampling menggunakan probability sampling dengan pendekatan simple random sampling dan didapatkan total 40 responden. Efikasi diri diukur menggunakan kuesioner sedangkan IDWG pasien sebagian diukur dengan timbangan dan sebagian lainnya hanya menulis berat badan yang diingat oleh pasien di lembar kuesioner. Kuesioner yang digunakan terdiri dari 2 bagian, yaitu pengukuran efikasi diri pembatasan cairan sebanyak 7 pertanyaan dan efikasi diri pembatasan natrium sebanyak 4 pertanyaan. Nilai validitas dan reliabilitas 
kuesioner adalah 0,853 . Penelitian dilakukan bulan April 2018 sampai Mei 2018.

Hasil

\section{Analisa Univariat}

\section{Karateristik Responden}

Dibawah ini adalah gambaran karateristik responden di ruang hemodialisa RSUD Pasar Minggu.

Tabel 1. Distribusi Karateristik Responden Berdasarkan Usia Dan Lama HD

\begin{tabular}{ccc}
\hline $\begin{array}{c}\text { Karateristik } \\
\text { responden }\end{array}$ & Mean \pm SD & 95\% CI \\
\hline Usia & $56 \pm 10,846$ & 52,$53 ; 59,47$ \\
Lama HD & $18,82 \pm 19,592$ & 12,$56 ; 25,09$ \\
\hline
\end{tabular}

Dari data yang sudah dikumpulkan terhadap 40 responden, didapatkan hasil untuk rata - rata usia pasien gagal ginjal kronik yang menjalani Hemodialisis di Ruang Hemodialisa RSUD Pasar Minggu adalah 56, dengan standar deviasi 10,846. Sebanyak 95\% diyakini rata - rata usia responden adalah 52,53 sampai 59,47. Rata - rata lama menjalani hemodialisis pada pasien gagal ginjal di RSUD Pasar Minggu adalah 18,82 bulan dengan standar deviasi 19,592. Sebanyak 95\% diyakini rata - rata lama menjalani HD pasien adalah 12,56 sampai 25,09 .

Tabel 2. Distribusi Karateristik Responden Berdasarkan Jenis Kelamin

\begin{tabular}{ccc}
\hline Jenis Kelamin & n & $\%$ \\
\hline Laki - Laki & 30 & $75 \%$ \\
Perempuan & 10 & $25 \%$ \\
\hline
\end{tabular}

Hasil analisis terhadap jenis kelamin didapatkan distribusi jenis kelamin laki - laki ada 30 orang dengan jumlah presentase $75 \%$ dan pasien dengan jenis kelamin perempuan ada 10 orang dengan presentase $25 \%$.

\section{Efikasi Diri Pembatasan Cairan}

Tabel 3 Distribusi Efikasi Diri Pada Pasien Gagal Ginjal Kronik Di RSUD Pasar Minggu

\begin{tabular}{ccc}
\hline Efikasi Diri & n & $\%$ \\
\hline Tinggi & 20 & $50 \%$
\end{tabular}

\section{Rendah}

20 $50 \%$

Hasil analisa data untuk untuk efikasi diri didapatkan sebanyak 20 pasien memiliki efikasi diri yang tinggi dengan presentase $50 \%$ dan sebanyak 20 pasien lainnya memiliki efikasi diri rendah dengan frekuensi 50\%.

\section{IDWG}

Hasil rata - rata kenaikan berat badan intradialisis dalam $\mathrm{Kg}$ adalah 2,188 dengan standar deviasi 1,0044. Sebanyak 95\% diyakini rata - rata IDWG responden adalah 1,866 sampai 2,509 .

Tabel 4. Distribusi IDWG Pada Pasien Gagal Ginjal Kronik Di RSUD Pasar Minggu

\begin{tabular}{ccc}
\hline $\begin{array}{c}\text { Karateristik } \\
\text { responden }\end{array}$ & Mean \pm SD & $\mathbf{9 5 \%}$ CI \\
\hline IDWG & $2,188 \pm 1,0044$ & 1,$866 ; 2,509$ \\
\hline
\end{tabular}

\section{Analisa Bivariat}

Dibawah ini adalah analisa hubungan efikasi diri pembatasan cairan dengan IDWG.

Tabel 5. Hubungan Efikasi Diri Pembatasan Cairan dan IDWG

\begin{tabular}{cccc}
\hline $\begin{array}{c}\text { Efikasi } \\
\text { Diri }\end{array}$ & n & Mean Rank & P Value \\
\hline Tinggi & 20 & 11,48 & 0,001 \\
Rendah & 20 & 29,52 & \\
\hline
\end{tabular}

Dari data penelitian yang sudah didapatkan, nilai mean rank untuk Efikasi diri tinggi adalah 11,48 sedangkan untuk efikasi diri rendah adalah 29,52. Didapatkan nilai $\mathrm{p}$ value 0,001 . Nilai $\mathrm{P}$ value lebih kecil daripada 0,05 yang artinya terdapat hubungan antara efikasi diri pembatasan cairan dengan IDWG.

Selain efikasi diri pembatasan cairan, terdapat beberapa faktor lain yang juga dianalisis dengan IDWG yang bertujuan untuk mengetahui hubungan antara karateristik responden (usia, jenis kelamin dan lama HD) dengan IDWG.

Tabel 6. Hubungan Usia dan Lama HD dengan IDWG

\begin{tabular}{lccc}
\hline Variabel & n & $\begin{array}{c}\text { Spearman's } \\
\text { Rho }\end{array}$ & P Value \\
\hline
\end{tabular}




\begin{tabular}{llll}
\hline Usia & 40 & $-0,135$ & 0,405 \\
Lama HD & 40 & $-0,079$ & 0,627 \\
\hline
\end{tabular}

Pada tabel, didapatkan angka Spearman's rho antara usia dengan IDWG adalah - 0,135 dimana angka tersebut berarti tidak terdapat hubungan atau hubungan bersifat lemah antara usia dengan IDWG dan hubungan tersebut berpola negatif atau berbalik. Semakin tua usianya maka semakin kecil IDWGnya. Didapatkan p value sebesar 0,405 . Angka $\mathrm{p}$ value lebih besar dari 0,05 yang artinya tidak terdapat hubungan yang signifikan antara usia dengan IDWG. Selain itu, data tabel juga menunjukan nilai Spearman's rho untuk Lama HD adalah -0,079 dimana nilai ini adalah nilai yang rendah dan berpola negatif, artinya semakin lama menjalani HD, maka semakin rendah atau kecil IDWGnya. Hasil uji statistik didapatkan nilai $\mathrm{p}$ value adalah 0,627 dimana nilai ini lebih besar dari 0,05 yang artinya tidak terdapat hubungan yang signifikan antara lama menjalani HD dengan IDWG.

Tabel 7. Hubungan Jenis Kelamin dan IDWG

\begin{tabular}{lccc}
\hline Jenis Kelamin & $\mathbf{n}$ & Mean \pm SD & P Value \\
\hline Laki - Laki & 30 & $2,133 \pm 1,0417$ & 0,561 \\
Perempuan & 10 & $2,350 \pm 0,9144$ & \\
\hline
\end{tabular}

Berdasarkan hasil penelitian
didapatkan bahwa rata rata IDWG pasien laki
laki lebih rendah yaitu $2,133 \mathrm{Kg}$ dengan
variasi 1,0417 dibandingkan dengan pasien
perempuan yaitu rata-rata 2,350 dengan variasi
0,9144 . Hasil uji T didapatkan nilai $\mathrm{p}=0,561$
berarti secara statistik tidak ada perbedaan
yang signifikan antara IDWG laki - laki
dengan IDWG perempuan.

\section{Pembahasan}

Efikasi diri adalah keyakinan seseorang akan keberhasilan dalam melakukan perawatan diri untuk mencapai hasil yang diinginkan. ${ }^{9}$ Efikasi diri merupakan salah satu faktor penentu nilai IDWG. Hal ini disebabkan karena self efikasi berfokus pada pengendalian intake cairan, sodium, protein dan zat lain yang mempengaruhi kenaikan berat badan intradialisis pada pasien gagal ginjal kronik yang menjalani hemodialisa. Tidak terdapat hubungan signifikan antara efikasi diri dengan 604
IDWG meskipun pasien sudah diberikan edukasi. ${ }^{9}$

Training efikasi diri atau latihan untuk mengasah efikasi diri sangat baik untuk meningkatkan kepatuhan terhadap intake cairan yang dapat dilihat dari penurunan rata rata IDWG. ${ }^{10}$ Pemberian edukasi atau training efikasi merupakan suatu persuasi sosial yang menyampaikan informasi lewat seseorang yang berpengaruh untuk meyakinkan pasien akan kemampuannya dalam membatasi cairan. Dan hal ini membuktikan adanya hubungan antara efikasi diri dengan IDWG pada pasien gagal ginjal kronik yang menjalani hemodialisa.

Hasil penelitian menunjukkan bahwa terdapat hubungan signifikan antara diet pembatasan cairan dengan IDWG melewati konseling transaksional. ${ }^{7}$ Hal ini membuktikan bahwa pasien yang diberikan konseling akan mematuhi diet cairannya sehingga hal ini mempengaruhi IDWG pasien. Hal yang menjadi fokus utama penelitian ini adalah mengurangi rasa haus pasien. Untuk itu diberikan sejumlah konseling yang diharapkan mampu membuat pasien mengontrol rasa hausnya dan mematuhi diet cairannya.

Efikasi diri pembatasan cairan mempengaruhi IDWG melewati kepatuhan pasien terhadap pembatasan intake cairan dan sodium. Hal ini dikarenakan, penurunan laju filtrasi glomelurus akan kemampuan reabsorbsi ginjal terhadap cairan berkurang. Sehingga cairan akan menumpuk dan menyebabkan overload. ${ }^{2}$ Kenaikan berat badan intradialisis diatas $1,5 \mathrm{~kg}$ akan menyebabkan pasien mengalami gangguan kesehatan seperti edema, sesak nafas dan gangguan kardiovaskular lainnya. Selain itu konsumsi sodium atau garam juga memperburuk kondisi kesehatan pasien gagal ginjal. Hal ini dikarenakan mengkonsumsi garam akan membuat pasien merasa haus yang disebabkan oleh osmometrik. ${ }^{6}$ Penumpukan jumlah garam akan menyebabkan volume cairan ekstraseluler meningkat. Hal ini juga ikut meningkatkan tekanan darah. Dalam hal ini, peranan ginjal adalah untuk membuang kelebihan garam dalam tubuh sehingga tubuh mencapai keseimbangan. Jika jumlah natrium dalam tubuh menurun, maka volume ekstraseluler akan menurun dan tekanan darah ikut 
menurun. Hal ini juga membuat laju filtrasi glomelurus ikut menurun. ${ }^{11}$

Efikasi diri pembatasan cairan yang memiliki korelasi negatif dengan IDWG adalah menghindari makan makanan pedas, minum hanya untuk menelan obat, menghidari sinar matahari, menghindari untuk menyesap air lebih dari kebutuhan sehari dan minum minuman beralkohol. Sedangkan untuk pembatasan garam yang memiliki korelasi negartif dengan IDWG adalah menghindari garam diatas meja dan mengecek kadar garam pada label makanan. ${ }^{12}$ Hal ini bisa berbeda dengan penelitian ini sebab gaya hidup yang berbeda antara 2 negara yang berbeda.

Faktor - faktor lain yang juga mempengaruhi IDWG dalam penelitian ini adalah usia, jenis kelamin dan lama HD. Menurut Istanti, koefisien determinan usia berada pada angka 3,1\% yang menunjukan bahwa usia hanya mempengaruhi sekitar 3,1\% faktor yang mempengaruhi IDWG sedangkan 96,9\% lainnya ditentukan oleh faktor lain. Pada usia yang lebih tua, belum tentu akan mengalami kenaikan IDWG apabila tidak ditunjang dengan pengetahuan dan pengalaman. Sementara itu, ketidakpatuhan yang berdampak pada IDWG dipandang sebagai kelalaian dan kurangnya pengendalian diri dan penguasaan terhadap lingkungan dan bukan berdasarkan pengaruh tingkatan usia. Hal ini seperti yang ditunjukkan pada penelitian lain yang juga menunjukkan tidak adanya hubungan yang signifikan antara usia dengan IDWG. ${ }^{13}$ Peningkatan IDWG dapat terjadi pada semua usia berdasarkan kepatuhan dan pengaturan intake cairannya. Hal ini tidak sejalan dengan penelitian lain bahwa usia memiliki hubungan signifikan dengan IDWG. ${ }^{14}$ Usia dapat mempengaruhi IDWG dikarenakan penurunan sensasi haus yang disebabkan karena proses penuaan dan adanya disfungsi serebral dan penurunan sensitivitas osmoreseptor. Hal tersebut membuat intake cairan berkurang sehingga mengurangi kenaikan berat badan intradialisisnya.

$60 \%$ air total tubuh membentuk berat badan pada laki - laki sedangkan pada perempuan hanya berkisar $50 \%$. Selain itu, laki - laki memiliki tubuh dengan komposisi yang banyak dipenuhi otot, sedangkan perempuan dinilai memiliki lebih banyak lemak. Lemak sendiri merupakan zat yang bebas air sehingga membuat presentase air dari berat badan perempuan menjadi lebih sedikit. Hal ini memberikan dampak tingginya IDWG pada laki - laki daripada perempuan. ${ }^{15}$ Penelitian lain menyatakan bahwa IDWG dipengaruhi oleh jenis kelamin, walau begitu ia menemukan bahwa IDWG pada perempuan lebih besar daripada IDWG pada laki - laki ${ }^{14}$. Hal ini nampaknya sejalan dengan penelitian ini, dimana rata - rata IDWG pada perempuan lebih besar dibandingkan rata - rata IDWG pada laki - laki.

Lamanya menjalani hemodialisa tidak menjadi faktor penentu nilai IDWG. Hal ini dikarenakan lamanya hemodialisa pada pasien beragam, yang juga mempengaruhi IDWG pasien yang beragam pula Lamanya seseorang menjalani hemodialisa mempengaruhi tingkat pengetahuan mengenai pembatasan cairan dan pengontrolan berat badan intradialisis, kepatuhan terhadap pembatasan cairan yang akan mempengaruhi IDWG. Namun, hal demikian juga dapat berimplikasi bahwa semakin lama pasien menjalani hemodialisa, tidak menjamin pasien paham dan mematuhi diet pembatasan cairan protein dan garam yang dapat berdampak pada kesehatan pasien ${ }^{16}$.

\section{Kesimpulan}

Dalam penelitian ini dapat disimpulkan bahwa terdapat hubungan yang signifikan antara efikasi diri pembatasan cairan terhadap IDWG. Selain itu, ada faktor - faktor lain yang dapat mempengaruhi IDWG, namun pada penelitian ini, faktor - faktor tersebut ( usia, jenis kelamin dan lama HD) tidak memiliki hubungan yang signifikan dengan IDWG.

\section{Saran}

Pemberian edukasi di rumah sakit mengenai pentingnya pembatasan cairan dapat ditingkatkan dan dipantau melalui IDWGnya. Hal ini dapat meningkatkan efikasi diri pasien yang menjalani hemodialysis. Pada penelitian selanjutnya dapat terkiat tentang edukasi mengenai perilaku pasien menjelang jadwal HD, dimana kebanyakan pasien tidak mengontrol jumlah masukan makanan dan cairan di hari menjelang jadwal HD yang menyebabkan IDWG bertambah. Hal ini membahayakan kesehatan pasien gagal ginjal kronik. 


\section{Daftar Pustaka}

1. Chironda , G., Bhengu, \& Manwere. Adherence of Adult Chronic Kidney Disease patients with regard to their dialysis, medication, dietary and fluid restriction . Res J of Health Sci. Vol 5(1), 2017; 3 - 17.

2. Baradero, M., Dayrit, M. W., \& Siswadi, Y. Seri Asuhan Keperawatan Klien Gangguan Ginjal. Jakarta: Buku Kedokteran EGC; 2009.

3. RISKESDAS. Badan Penelitian dan Pengembangan Kesehatan Kemetrian Kesehatan RI; 2013.

4. Smeltzer, S. Keperawatan Medikal Medah Bruner \& Suddarth Edisi 12. Jakarta: Buku Kedokteran EGC; 2014.

5. Huddak, \& Gallo. Keperawatan Kritis . Jakarta: EGC; 2006.

6. Sharaf, A. Y. (2016). The Impact of Educational Interventions on Hemodialysis patient's Adherence to Fluid and Sodium Restriction. IOSR Journal of Nursing and Health Science (IOSR-JNHS). 2016; 50 - 60.

7. Hidayati , S., Sitorus, R., \& Masfuri. Efektifitas Konseling Analisis Transaksional tentang Diet Cairan terhadap Penurunan IDWG pasien Gagal Ginjal Kronis yang Menjalani Hemodialisa di RSUD Kardinas. 2015.

8. Rahimi, F., Oskouie , F., Naser , O., Sanandji, M. E., \& Gharib, A. (2017). The Effect of Self Care on Patients Undergoing Haemodialysis in The Sanandaj Hospital affiliated to Kurdistan University of Medical Sciences in 2016. Bali Med Journal Vol. 6. 2017; 684 689.

9. Wayunah, Saefulloh, M., \& Nuraeni, W. Penerapan Edukasi Terstruktur Meningkatkan Self Efficacy dan Menurunkan IDWG Pasien Hemodialisa di RSUD Indramayu. Jurnal Pedidikan Keperawatan Indonesia Vol. 2. 2016.

10. Sulistyaningsih, D. R. Efektifitas Trainig Efikasi Diri pada Pasien Penyakit Ginjal Kronik dalam Meningkatkan Kepatuhan Terhadap Intake Cairan; 2018.

11. William.. Fisiologi Keseimbangann Cairan dan Hormon yang Berperan. J. Kedokt. Meditek Vol. 23 No. 61. 2017; 69 - 73.
12. Christovao , A. F. Fluid and Dietary Restriction's Effficacy on Chronic Kisney Disease Patients in Hemodialysis. Departement of Medical Surgical Nursing, Nursing \& Adult Ederly, Lisboa Portugal. 2015.

13. Mustikasari, I., \& Noorratri, E. D. FaktormFaktor yang Mempengaruhi Nilai Interdialytic Weight Gain pasien Hemodialisa di RSUD Penembahan Senopati Bantul. Gaster Vol. XV No. 1. 2107.

14. Nerbass, F. B., Morais, J. G., dos Santos, R. G., Kruger, T. S., Koene, T. T., \& da Luz Filho, H. A. (2011). Factors Related to Interdialytic Weight Gain in Hemodialysis Patients . J Bras Nefrol 33 (3). 2011; 300 305.

15. Istanti, Y. P. Hubungan antara Masukan Cairan dengan Interdialytic Weight Gain (IDWG) Pada Pasien Chronic Kidney Disease di Unit Hemodialisis RS PKU Muhamadiyah Yogyakarta. Jurnal Profesi Vol. 10; 2014.

16. Bayhakki, \& Hasneli, Y. Hubungan Lama Menjalani Hemodialisa dengan Inter-dialytic Weight Gain (IDWG) pada Pasien Hemodialisa . JKP Vol. 5 No. 3. 2017; 242 248. 